\author{
St ud i P hilos o p hi c a \\ Wr a t i s l a vi e n s i a \\ vol. XIII, fasc. 4 (2018) \\ DOI: $10.19195 / 1895-8001.13 .4 .8$
}

\author{
MICHA£ KOZŁOWSKI \\ ORCID: 0000-0002-0889-928X
}

Uniwersytet Warszawski

\title{
W sprawie Znaków równości
}

Na początku chciałem wyrazić wdzięczność czytelnikom Znaków równości za przychylną lekturę. Wszyscy wiemy, że chociaż stanowi ona jedno z pierwszych przykazań naukowej hermeneutyki, to - jak to z przykazaniami bywa - obowiązuje jedynie jako postulat. Tym bardziej że ze Znakami równości sprawa wcale nie była oczywista. Nie dlatego, że to książka prowokująca czy epatująca skrajnością, a raczej dlatego, że na równych prawach występują w niej uświęcone pojęcia filozoficzne i kategorie bardzo podejrzanej proweniencji: opowieści historyczne, etnograficzne studia przypadku, hipotezy socjologiczne, a nawet raport z badań psychologicznych. Z humanistycznym przykazaniem miłości do multidyscyplinarności jest nie inaczej niż z przykazaniem miłości w ogóle - musi ono spełnić tyle warunków, że ostatecznie często sprowadza się do taktycznej obrony własnych wewnątrzdyscyplinarnych interesów. Tymczasem autor dostąpił dobrodziejstw owego przykazania bezwarunkowo.

Książka jest hybrydą w jeszcze jednym sensie. Adam Chmielewski skonstatował pewną jej francuskość. Nie będę się bronił przed tą oceną, tym bardziej że wedle wszelkiego prawdopodobieństwa nie chodzi tu o zarzut. Chciałbym jednakże dorzucić pewne uściślenie. Istotnie, odniesienia do literatury francuskiego pochodzenia są w tej pracy najliczniejsze (choć zapewne nie mają większości bezwzględnej). Co jednak ważniejsze, moja trajektoria naukowa istotnie bardzo silnie naznaczona jest tradycją francuskich nauk społecznych, rozciagającą się od Durkheima do Bourdieu i często przeciwstawianą swojej niemieckiej siostrze bliźniczce, rozpościerającej się od Webera do Habermasa. Tę pierwszą tradycję odróżnia od drugiej między innymi nieufny lub wprost negatywny stosunek do kategorii teleologicznych i normatywnych. W pewnym uproszczeniu: tam, gdzie tradycja niemiecka pyta o (transcendentalną) legitymizację normy społecznej, tradycja francuska będzie pytała raczej o jej (faktyczną) prawomocność. Jednocześnie mam nieodparte, cho- 
ciaż trudne do sprecyzowania wrażenie, że owa „francuskośc” jest pozorna lub powierzchowna. Już samo zestawienie Michela Foucault i Pierre'a Bourdieu i zaprzęgnięcie ich do wspólnej pracy uznane byłoby we Francji co najmniej za nietakt lub ekstrawagancję. Foucault i Bourdieu wyznaczaja tam bowiem zwykle alternatywę rozłączną. Gdyby książka ukazała się we Francji, z pewnością nie zostałaby uznana za produkt rodzimy i to wcale nie ze względu na pochodzenie autora (Francja ma pokaźną liczbę zagranicznych badaczy, którzy tworzą naukę jak najbardziej „rdzenną”). Jest to bowiem przykład transferu intelektualnego na odległość nie mniejszą, niż ma to miejsce w wypadku słynnej amerykańskiej French Theory, niezależnie od tego, że podróż odbywa się w innym kierunku.

Przejdźmy jednak do kwestii zasadniczych. Krytyka moich teoretycznych poczynań ze strony recenzentów jest niezwykle łagodna, więc nie pozostaje nic innego, niż przyznać, iż jest ona zasadniczo trafna, a jednocześnie upierać się przy swoim. Odniosę się do trzech kwestii: dwóch natury ogólnej i jednej szczegółowej. Wszystkie trzy są jednak kluczowe. Adam Chmielewski i Joanna Hańderek przedstawiają zarzut podobny, chociaż sformułowany z innych pozycji. Otóż, obydwoje sądzą, że strategia teoretycznego samoograniczenia, jawnie zresztą przeze mnie deklarowana, przynosi więcej szkody niż pożytku. Z jednej strony, brakuje Znakom zmierzenia się z uniwersum kluczowych pojęć filozofii polityki, takich jak suwerenność, demokracja, prawa człowieka; co za tym idzie — brakuje też analizy podstawowych kategorii ekonomii politycznej: własności, podziału pracy, dystrybucji i redystrybucji. Brakuje wreszcie czegoś na kształt historycznej głębi świata społecznego, którą za Heglem rozwijała szkoła frankfurcka. Co do tej ostatniej, to jestem przekonany, że, aby zrozumieć współczesny wielki powrót skrajnej prawicy, istotnie powinniśmy jeszcze raz powrócić do wielkich i, szczerze mówiąc, nieco zapomnianych tematów frankfurtczyków, szczególnie ich prób zrozumienia faszyzmu. Jednak moja książka ma bardzo ograniczone ambicje w kwestii aktualności. Zgadzam się, że owe braki mojej pracy czynią ją znacznie mniej pożyteczną (zdatną do bezpośredniego użycia), a także nie pozwalają zaspokoić filozoficznej ciekawości zarówno w kwestii przekraczania horyzontu, jak i poszukiwania całości.

Sądzę jednak, że w naukach społecznych samoograniczenie jest cnotą. Nie jest to cnota jedyna, bo ta dziedzina potrzebuje wielu, czasem wykluczających się wzajemnie cnót. Oznacza to, że nie uważam pytań o instytucje polityczne, ekonomię polityczną, sposoby konstruowania wspólnoty czy wreszcie pytań o „historyczną głębię", ekonomię libidynalną czy intersubiektywność za niepotrzebne, źle postawione czy też obłożne jakimś innym tabu. Jednak te pytania do pewnego stopnia determinują odpowiedzi, które możemy uzyskać. Odpowiedzi tego rodzaju mają skłonność do swoistego imperializmu, tendencję do kompletności i samozwrotności. Sądzę, że największa (i wcale nie powszechnie rozpoznana) zasługa stylu Michela Foucaulta polegała nie tyle na mocy anulowania dotychczasowych pytań, ile na umiejętności ich zawieszania. Różnica jest wbrew pierwszemu wrażeniu zasadnicza. Albowiem badanie Foucault to nie na u ka now a, lecz d o dat kowa. Nie mylić z nauką pomocniczą - to raczej nauka przeszkadzajacca. Foucault potrafił zawieszać pytanie o prawdę (co miało efekt skandalu), pytanie o celowość (co zapewne nie było przełomem), lecz także pytanie o istotę zjawiska, a nawet pytanie 
o związek przyczynowo-skutkowy. Oczywiście, nie zawieszał wszystkich tych pytań jednocześnie i bezwzględnie. Jednak to właśnie odmowa próby odpowiedzi na pewną liczbę pytań pozwala przekształcić pole poznawcze w taki sposób, że nawet jeśli dawne pytania powracają, to już zmienione. Idea rekonstrukcji praktyk i stosunków równościowych z perspektywy rządzenia, ustanawiania, sprawczości zdominowanych i wykluczajaccego uniwersalizmu miała właśnie przebiegać w poprzek (a nie pod prąd) głównych kategorii filozofii społecznej i politycznej. Miała zawieszać niektóre związane z nimi pytania, aby przekształcić pole poznawcze. Na ile się to udało, pozostaje do oceny czytelników. Wierzę jednak, że warto było spróbować.

Czas na kwestię szczegółową. Michał Herer przyłapał mnie na dość topornym przedstawieniu idei równości szans raczej jako ideologicznej zasłony rzeczywistych stosunków społecznych, zamiast rozpoznania w niej technologii rządzenia realnie uczestniczacej w tych stosunkach. Nie przeczę, że dałem pewne powody dla takiego osądu. Nie taka była jednak moja intencja. Jeśli pragnąłem wyróżnić „równość szans" spośród innych urządzeń jednocześnie stymulujących i ograniczających stosunki równościowe - a jest ich wszak niemało - to z innego powodu. Chodziło mi elegancję intelektualnej konstrukcji tego urządzenia. Otóż, nie przychodzi mi do głowy żadne inne urządzenie, które postuluje w istocie społecznie radykalną koncepcję równości, usprawiedliwiając ją celem antyrównościowym. I zarazem odwrotnie: faktyczną nierówność uzasadnia jej równościowym pochodzeniem. Nie o pozór zatem mi chodziło, lecz raczej o specyficzną i, szczerze powiedziawszy, dość złowrogą dialektykę zawartą w tym pojęciu.

Żywię natomiast przekonanie, że w Znakach równości zarysowane są dwa wątki, które domagają się rozwinięcia. Pierwszy pojawia się w rozdziale poświęconym Ambedkarowi i dotyczy fałszywego prestiżu. Moim pierwotnym założeniem było, że prestiż (uznanie, kapitał symboliczny) jest jednym z trzech elementarnych zasobów społecznych, które obejmuje kwesta równości. W jaki sposób zatem prestiż mógłby być fałszywy? Otóż, tak samo jak waluta, której nie da się wymienić na inne waluty. Zasoby społeczne muszą być wymienialne na inne zasoby, nawet jeśli sposób i kurs wymiany nie jest oczywisty. Jednak coś, co wygląda jak prestiż, a nie jest wymienialne na inne zasoby, jest prestiżem pozornym. Pytanie, jaką właściwie rolę odgrywa fałszywy prestiż w stosunkach społecznych, wydaje mi się wielce obiecujące.

Drugi wątek dotyczy pojęcia kapitału. Wiele wskazuje na to, że to pojęcie Marksa daleko wykracza poza swoje pierwotne zastosowanie do ekonomii politycznej kapitalizmu. Kapitał rozumiany jednocześnie jako zasób relacyjny, prywacyjny i kooperacyjny wydaje się jednym z najważniejszych odkryć nauk społecznych. Jednak to pojęcie jest niedostatecznie doceniane, lub raczej, będąc doceniane, jest systematycznie rozmazywane i przeinaczane. Wielce obiecujące wydaje się więc ponowne jego opracowanie, oczywiście przy uwzględnieniu wszelkich jego wieloznaczności i wewnętrznych napięć, innymi słowy, jego historyczności. 